\title{
The pectoralis myofascial flap in laryngeal surgery
}

\author{
Larenks cerrahisinde pektoral miyofasyal flep uygulaması \\ Yılmaz Özkul', Murat Songu', Seçil Arslanoğlu', Rıza Dündar², Mehmet Uçar', Ercan Pınar', Kazım Önal' \\ ${ }^{1}$ Department of Otorhinolaryngology, Izmir Katip Çelebi University Atatürk Training and Research Hospital, Izmir, Turkey \\ ${ }^{2}$ Department of Otorbinolaryngology, Harran University Medical Faculty, Sanliurfa, Turkey
}

\begin{abstract}
Objective: To report our experience about pedicled pectoralis major myocutaneous flap (PMMF) for the treatment of pharyngocutaneous fistula (PCF).

Methods: Between June 2006 and September 2014, 202 consecutive total laryngectomies for laryngeal or hypopharyngeal squamous cell carcinoma were performed in our hospital. The medical records of the patients were retrospectively reviewed to document the development of a PCF.

Results: PCF developed in 45 of 202 patients (22\%) in the study group. Of these 45 patients, spontaneous closure with local wound care was achieved in 33 patients (73\%). Remaining 12 patients required surgical closure with PMMF. Four of 12 patients (25\%) had complications after surgical closure with PMMF. Radiotherapy had been performed before laryngectomy in 16 of 45 patients with PCF. Of these 16 patients who developed PCF and have had previous radiotherapy, spontaneous closure with local wound care was achieved in four cases, while PMMF was used in the remaining 12 cases.
\end{abstract}

Conclusion: Pedicled pectoralis major myocutaneous flap is a good reconstructive option in the treatment of PCF formation following total laryngectomy surgery.

Keywords: Pharyngocutaneous fistula, total laryngectomy, pedicled pectoralis major myocutaneous flap.

The development of a pharyngocutaneous fistula (PCF) remains the most common and challenging complication following total laryngectomies. It leads to delays of the adjuvant treatments and prolonged hospitalization. ${ }^{[1]}$ Current management trends have favoured radiation or chemoradiation over surgical options in the spirit of that goal. As a result, there have been a growing number of

\section{Özet}

Amaç: Farengokutanöz fistül (FKF) tedavisinde pediküllü pektoralis majör miyokütanöz flep (PMMF) kullanımında edinilen tecrübelerin paylaşımı amaçlanmıştır.

Yöntem: Haziran 2006 ve Eylül 2014 döneminde hastanemizde 202 ardışık larenks ve hipofarenks skuamöz hücreli karsinom larinjektomisi gerçekleştirilmiştir. Hastaların tıbbi kayıtları geçmişe dönük olarak incelenerek FKF oluşumu dokümante edilmiştir.

Bulgular: Çalışma kapsamındaki 202 hastanın 45'inde (\%22) FKF gelişmiştir. Bu 45 hastanın 33 'ünde lokal yara bakımı ile spontane kapanma sağlanmıştır (\%73). Geri kalan 12 hastaya PMMF ile cerrahi kapama yapılması gerekmiştir. Bu 12 hastadan 4'ünde PMMF ile cerrahi müdaheleden sonra komplikasyon gelişmiştir. FKF görülen 45 hastanın 16'sında larinjektomi öncesi radyoterapi uygulanmıştır. FKF gelişimi görülen ve daha önce radyoterapi uygulanan bu 16 hastadan dört vakada lokal yara bakımı ile yara kapanımı gerçekleşmiştir, geri kalan 12 vakada PMMF kullanılmıştır.

Sonuç: Total larinjektomi sonrası FKF oluşumunun tedavisi için PMMF uygulaması iyi bir rekonstrüktif uygulamadır.

Anahtar sözcükler: Faringokutanöz fistül, total larenjektomi, pediküllü pektoralis majör myokutanöz flebi.

patients presenting with recurrent disease requiring salvage laryngectomy. Multiple factors have been shown to contribute to the development of PCF, including prior radiotherapy, chemotherapy, malnutrition, duration of surgery, anemia, tobacco use, and medical comorbidities. ${ }^{[1,2]}$

It has been recently shown that introduction of vascularized tissue at the time of initial pharyngeal closure
Correspondence: Yılmaz Özkul, MD. Department of Otorhinolaryngology, Izmir Katip Çelebi University Atatürk Training and Research Hospital, Izmir, Turkey.

e-mail: yilmazozkul@mynet.com

Received: December 1, 2014; Accepted: December 21, 2014
Online available at: www.jmedupdates.org doi:10.2399/jmu.2014003006 QR code: 
reduces the fistula rate and need for operative intervention. However, primary closure of salvage laryngectomy defects remains the standard-of-care at most institutions. ${ }^{[3,4]}$ First popularized by Ariyan, the pedicled pectoralis major myocutaneous flap (PMMF) has been the workhorse flap for this indication. ${ }^{[1,4]}$

Herein, we aimed to present our experience and the reconstructive strategy refined from this experience as applied to pharyngocutaneous defects after total laryngectomy in a review of 12 patients who underwent secondary fistula repair.

\section{Materials and Methods Study Design}

Between June 2006 and September 2014, 202 consecutive total laryngectomies for laryngeal or hypopharyngeal squamous cell carcinoma were performed in our tertiary center. The medical records of the patients were retrospectively reviewed to document the development of a PCF. The collected data included patient demographics, treatment modalities, and complications including the development and management of postoperative PCF.

\section{Surgical Repair with Pedicled Pectoralis Major Myocutaneous Flap}

The pharyngeal edges are sharply debrided and sent for routine pathology (Fig. 1). Flap design was performed as follows: The axis of rotation is a line drawn from the coracoid process of the scapula to the xiphoid process (Fig. 2). This line marks the course of the thoracoacromial vessels as they branch from the axillary vessels just medial to the pectoralis minor insertion. The skin island is an ellipse positioned over the muscle medial to the nipple and lateral to the sternal edge. The most inferior part of the ellipse is at the inframammary fold. The initial incision is made at the lateral part toward the anterior axillary line down to the pectoralis major muscle. The maximum amount of muscle should be harvest, because the larger the muscle volume, the safer the flap due to the increased number of myocutaneous perforators. The inferior, medial and lateral incisions are made through the skin, subcutaneous fat and pectoralis fascia down to the chest wall (Fig. 3). As the muscle is elevated from inferior to superior, the pedicle should be identified by palpation and visualization on the deep surface of the muscle (Fig. 4). The pectoralis major muscle derives its blood supply from the pectoral branch of the thoracoacromial artery and lateral thoracic artery. When the muscle fibres are cut along the sternal attachment, special attention should be taken not to cut the internal mammary perforators adjacent to the sternum that supply the deltopectoral flap. During the dissection the vascular bundle should always be seen in order to avoid injury to this bundle. Concerning closure of the donor-side, we perform primary closure.

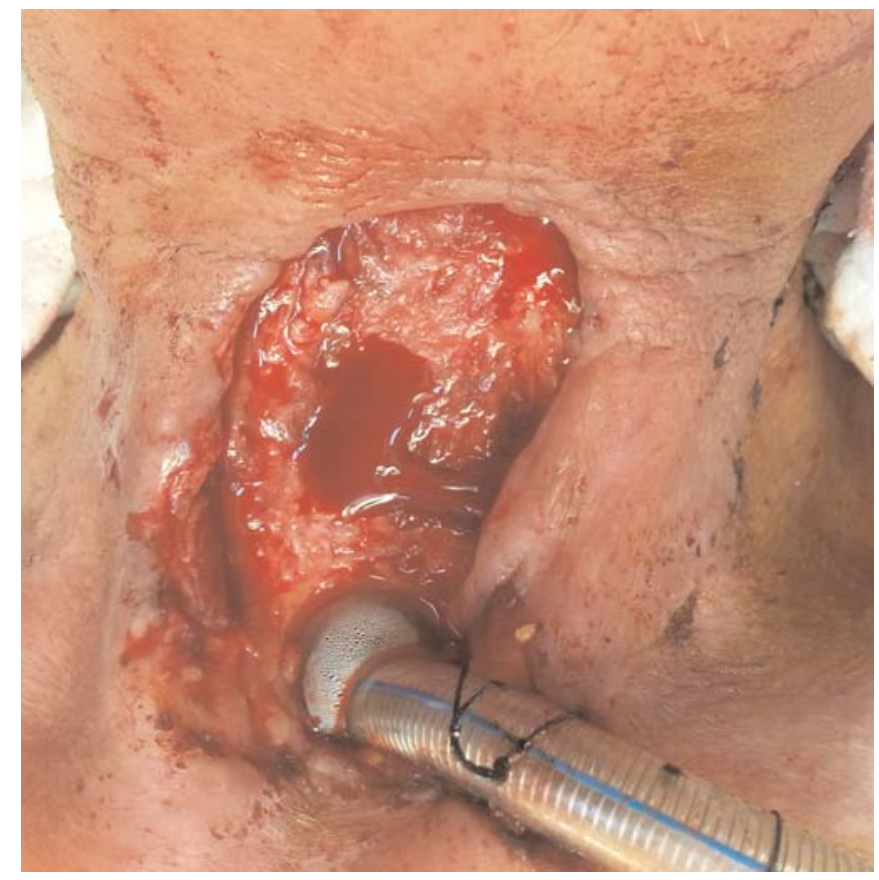

Fig. 1. The pharyngeal edges are sharply debrided and sent for routine pathology.

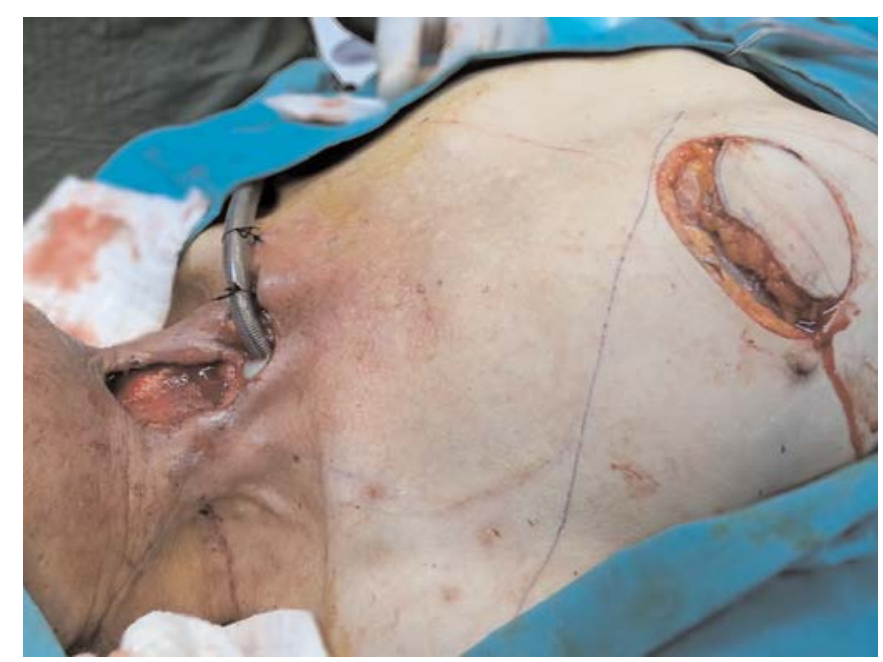

Fig. 2. The axis of rotation is a line drawn from the coracoid process of the scapula to the xiphoid process. 


\section{Results}

A total of 202 patients were included in the study. There were 173 males $(86 \%)$ and 39 females (14\%), and the mean patient age was 63 (range: 42 to 79 ) years. The mean follow-up of the study population was 36 months.

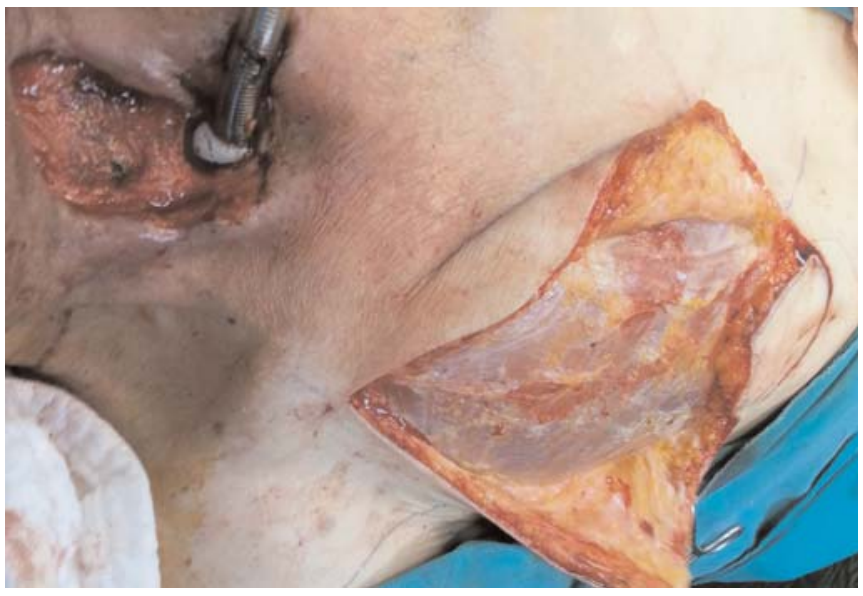

Fig. 3. The flap is raised from the anterior chest wall in the sub-muscular plane.

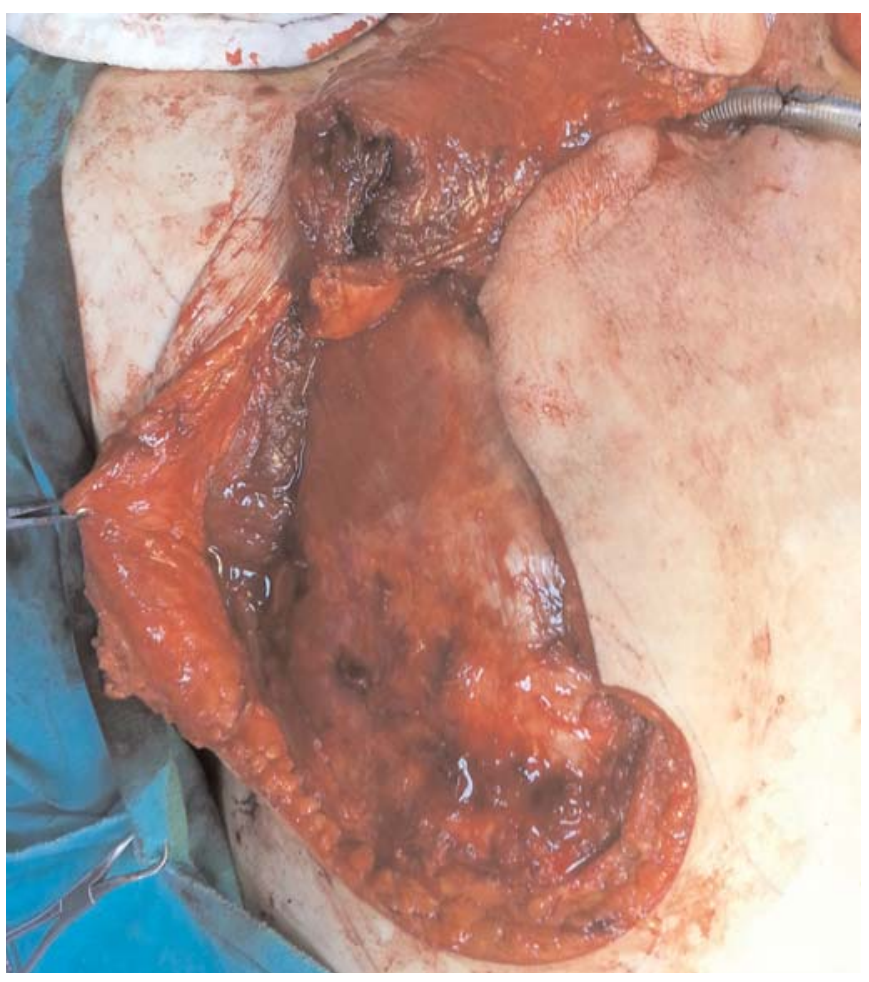

Fig. 4. The flap is positioned over the defect.
All patients had a history of squamous cell carcinoma of the larynx, and all but three patients had a history of tobacco smoking. Radiotherapy has been administered to 21 $(10.3 \%)$ patients preoperatively.

PCF developed in 45 of 202 patients (22\%) in the study group. Of these 45 patients, spontaneous closure with local wound care was achieved in 33 patients $(73 \%)$. Remaining 12 patients required surgical closure with PMMF. Four of 12 patients $(25 \%)$ had complications after surgical closure with PMMF. Radiotherapy had been performed before laryngectomy in 16 of 45 patients with PCF. Of these 16 patients, who developed PCF and have had previous radiotherapy, spontaneous closure with local wound care was achieved in four cases, while PMMF was used in the remaining 12 cases.

Two patients developed pharyngeal stenosis and treated with repeated dilatations. One patient had partial flap necrosis, which required secondary intention after debridement. One patient, who had received radiotherapy before PMMF closure, had fistula recurrence, which did not respond to revision surgery. The patient died of aspiration pneumonia. In 12 patients who required surgical closure with PMMF, the mean healing time was $39 \pm 32$ days compared with $19 \pm 12$ days in the group of patients in whom the fistula did not develop.

\section{Discussion}

The incidence of PCF after total laryngectomy is extremely variable, with values ranging from $5 \%$ to $65 \%$. However, a rate between $13 \%$ and $25 \%$ has been frequently reported over the last two decades (5). The observation of 45 fistulas (22\%) in our group of 202 patients is consistent with the mean values.

Preoperative radiotherapy was an etiologic factor also deemed controversial and inconclusive among various research studies. Radiotherapy has been related to fistula development because of the diminished healing capacity of irradiated tissues. Modernization of radiotherapy techniques and use of cobalt-related linear accelerators have diminished the frequency of reports linking radiotherapy and fistula formation. Recent studies do not incriminate radiotherapy as a predisposing factor contrary to previous, older research efforts. ${ }^{[5-7]}$ Even though much controversy still surrounds the prevention of pharyngocutaneous fistulas, it is generally agreed that most fistulas respond well to conservative management. The differences appear to be mainly related to previous radiotherapy: spontaneous closure was achieved in $44 \%$ to $82 \%$ of previously treated 
patients versus $80 \%$ to $95 \%$ of patients who had not been previously treated. ${ }^{[1,3,8]}$ In the present study, radiotherapy had been performed before laryngectomy in 16 of 45 patients with PCF. Of these 16 patients, who developed PCF and have had previous radiotherapy, spontaneous closure with local wound care was achieved in four cases, while PMMF was used in the remaining 12 cases.

The main vascular pedicle of the pectoralis major musculocutaneous flap is composed of the pectoral branches of thoracoacromial vessels. Ariyan had described that the intramuscular course of these branches is along a line from the tip of the shoulder to the xiphoid process. Traditionally, the skin island has been designed on the basis of the estimated location of this pedicle..$^{[9]}$

The role of the PPMF has continued to evolve as free flap surgery has become established throughout the world. In 2010, Liu et al. reported on 202 PMMFs performed during the period of 1998-2008 in Hong Kong. The PPMF was increasingly used for salvage surgery of the oral cavity, although it was still being used more frequently for immediate reconstruction rather than salvage surgery $(70 \%$ compared with 29\%). In a recent series by You et al. from Korea, over a similar time period to the current study, 120 PMMFs were used for comparable indications within a practice that also utilizes free flap transfer. A recent smaller series of 55 PMMFs from the USA by Schneider et al. described similar findings, but the differences were that a second free flap was used more frequently after initial free flap failure and the PPMF was more often combined with a free flap. ${ }^{[10,11]}$

Limitations of our study include the retrospective design and relatively small number of our series. In addition, some details of history and factors that may influence the outcome may not be completely documented. Due to these restrictions, associations should be interpreted with caution.

\section{Conclusion}

Although most fistulas close spontaneously and can be managed conservatively without surgical intervention, this complication represents a challenge to the head and neck sur- geon, and leads to prolonged hospitalization, increased patient morbidity and more complicated rehabilitation.

Conflict of Interest: No conflicts declared.

\section{References}

1. Bohannon IA, Carroll WR, Magnuson JS, Rosenthal EL. Closure of post-laryngectomy pharyngocutaneous fistulae. Head Neck Oncol 2011;3:29.

2. Eisbruch A, Lyden T, Bradford CR, et al. Objective assessment of swallowing dysfunction and aspiration after radiation concurrent with chemotherapy for head-and-neck cancer. Int J Radiat Oncol Biol Phys 2002;53:23-8.

3. Dirven R, Swinson BD, Gao K, Clark JR. The assessment of pharyngocutaneous fistula rate in patients treated primarily with definitive radiotherapy followed by salvage surgery of the larynx and hypopharynx. Laryngoscope 2009;119:1691-5.

4. Patel UA, Keni SP. Pectoralis myofascial flap during salvage laryngectomy prevents pharyngocutaneous fistula. Otolaryngol Head Neck Surg 2009;141:190-5

5. Erdag MA, Arslanoglu S, Onal K, Songu M, Tuylu AO. Pharyngocutaneous fistula following total laryngectomy: multivariate analysis of risk factors. Eur Arch Otorhinolaryngol 2013; 270:173-9.

6. Ikiz AO, Uka M, Guneri EA, Erdag TK, Sutay S. Pharyngocutaneous fistula and total laryngectomy: possible predisposing factors, with emphasis on pharyngeal myotomy. J Laryngol Otol 2000;114:768-71.

7. Redaelli de Zinis LO, Ferrari L, Tomenzoli D, Premoli G, Parrinello G, Nicolai P. Postlaryngectomy pharyngocutaneous fistula: incidence, predisposing factors, and therapy. Head Neck 1999;21:131-8.

8. Gilbert MR, Sturm JJ, Gooding WE, Johnson JT, Kim S. Pectoralis major myofascial onlay and myocutaneous flaps and pharyngocutaneous fistula in salvage laryngectomy. Laryngoscope 2014;124:2680-6.

9. Righini C, Lequeux T, Cuisnier O, Morel N, Reyt E. The pectoralis myofascial flap in pharyngolaryngeal surgery after radiotherapy. Eur Arch Otorhinolaryngol 2005;262:357-61.

10. Avery CM, Gandhi N, Peel D, Neal CP. Indications and outcomes for 100 patients managed with a pectoralis major flap within a UK maxillofacial unit. Int J Oral Maxillofac Surg 2014;43: 546-54.

11. Schneider DS, Wu V, Wax MK. Indications for pedicled pectoralis major flap in a free tissue transfer practice. Head Neck 2012;34:1106-10

This is an open access article distributed under the terms of the Creative Commons Attribution-NonCommercial-NoDerivs 3.0 Unported (CC BYNC-ND3.0) Licence (http://creativecommons.org/licenses/by-nc-nd/3.0/) which permits unrestricted noncommercial use, distribution, and reproduction in any medium, provided the original work is properly cited.

Please cite this article as: Özkul Y, Songu M, Arslanoğlu S, Dündar R, Uçar M, Pınar E, Önal K. The pectoralis myofascial flap in laryngeal surgery. J Med Updates 2014;4(3):113-116. 